\title{
Research on a Relationship between Patient Satisfaction and Medical Services in State Health Organizations
}

\author{
Alisardar Mammadov1*, Rahim Gasanov² \\ ${ }^{1}$ School of Business Administration, South China University of Technology, Guangzhou, China \\ ${ }^{2}$ Department of Business Administration, Institute of Social Sciences, Usak University, Usak, Turkey \\ Email: *alisardarm@hotmail.com, rehim.hesenov@gmail.com
}

How to cite this paper: Mammadov, A. and Gasanov, R. (2017) Research on a Relationship between Patient Satisfaction and Medical Services in State Health Organizations. American Journal of Industrial and Business Management, 7, 1255-1266. https://doi.org/10.4236/ajibm.2017.711089

Received: October 27, 2017

Accepted: November 27, 2017

Published: November 30, 2017

Copyright $\odot 2017$ by authors and Scientific Research Publishing Inc. This work is licensed under the Creative Commons Attribution International License (CC BY 4.0).

http://creativecommons.org/licenses/by/4.0/

\begin{abstract}
This research has been applied to the patients who were getting treatment in a state hospital and the perception of patients about hospital services and satisfaction has been examined. The 150 applied surveys were created using the SERFPERF scales and interviewed and implemented by the patients. As a result of the analysis, it was found that there is a positive relationship between medical service and patient satisfaction: Pre-service and physical services and examination services have a meaningful impact on patient satisfaction.
\end{abstract}

\section{Keywords}

Service Quality, Medical Services, Patient Satisfaction

\section{Introduction}

Increasing the average life expectancy almost all over the world increases the importance of the health sector at the same time. The health system has important and different characteristics. The main difference is that this sector is directly related to human life. At the same time, unlike other sectors, financial expenditures are much higher in terms of personnel and physical equipment. Especially the training processes of doctors and health personnel are longer and more costly than many other occupations.

The primary goal of health services is to meet the health expectations of communities and attract the service quality to higher levels (Cati and Yilmaz, 2002) [1]. Nowadays, the increase of spending has caused many developments in this sector.

Today, the development of the health sector and the increasing demand for it, 
have made the quality of the service provided by this sector more important. Robinson (1999) [2] defined service quality as an antecedent to consumer satisfaction.

According to Kayral (2014) [3] patients' perceptions regarding the service quality are significantly related with their satisfaction level. The most basic aim of health service organizations is to provide patient satisfaction. According to Zeithaml and Bitner (2000) [4], patients' satisfaction on medical care determines their consumer behavior: making positive comments about the hospital, preferring the hospital in case of need for seeking help, increasing the frequency of going to the hospital, willingness to pay for services at a higher cost.

Due to the nature of the services in general and the medical services in particular, the healthcare sector has a high degree of interaction with the patient. Therefore, studying the factors influence the satisfaction of patients has great research significance and patient satisfaction in its turn plays an important role in the success of the organizations providing medical services.

Excluding the conclusion part, this paper consists of three sections. In the first section, general introduction was presented and the significance of research was emphasized. In the second section, literature review and research methodology regarding with the current study had been discussed. In the third section of the study, based on survey questionnaires hypothesis testing was conducted and key findings were evaluated. Finally, the results analysis and possible future research topics discussed at the section of conclusion.

\section{Literature Review}

The most commonly used scale for service measurement is SERVQUAL scale, which was developed by (Parasuraman, Zeithaml and Berry) 1985, 1990 [5] [6]. According to Adil and Albkour (2013) [7] due to practicability and simplicity of SERVQUAL scale, it was supported by many different sectors, including health sector. Gronroos (1984) [8] suggests that there are three important dimensions of service quality: technical quality, functional quality and firm image. This scale is based on the measurement of the difference between the perceptions and expectations of the customer (Parasuraman, Zeithaml and Berry, 1985) [5], (Berry et al., 1985) [9]. There are also three distinct dimensions in Lehtinen and Lehtinen (1982)'s [10] research which are the physical quality, firm quality and interaction quality (Parasuraman, Zeithaml and Berry 1985) [5], (Ghobadian et al., 1994) [11]. Parasuraman (1988) [12] suggested that there are five dimension of service quality that might be applied to the service sector. At the same time, the authors emphasized that these five dimensions are the skeletal quality dimensions of service and, if necessary, can be adapted to other service organizations as well. These dimensions are explained below:

1. Physical Properties;

2. Reliability;

3. Enthusiasm; 
4. Confidence;

5. Empathy.

Customer satisfaction refers to what the service provider thinks about the extent to which the benefit the customer desires to receive, and what he thinks about the service and after service. McNealy (1994) [13] explains the concept of customer satisfaction with five principles. These principles are:

- Management has an important role in customer satisfaction. Within the service management industry, the management of the organization should work to increase the quality of service and to meet the demands of customers who need constantly renewed services;

- Customer satisfaction in terms of profitability is an important factor;

- Customer satisfaction is included the whole organization. Therefore the services provided by the organization is influential in the general customer satisfaction;

- Constant structuring is essential for the customer satisfaction. For this reason, the organization should constantly renew itself;

- Measurement of customer satisfaction in organization should be done with great precision.

According to Yilmaz (2010) [14], these five concepts also could be used in evaluating patient satisfaction in health services. Based on Sahin et al. (2005) [15] patient and patient relatives' satisfaction in health institutions highly influenced by factors such as medical care services, nursing services, laboratory services, healthcare staff attention, cleanliness, technological infrastructure, general hostel services, meal presentation, service speed, bureaucratic processes, management understanding, price and quality.

Till now several studies conducted on above-mentioned problem. Recently a comparative analysis conducted to measure service quality and patient satisfaction in two private health care organizations. The 5-point Likert questionnaire was prepared according to "SERVQUAL" method and 22 variables were obtained. Parasuraman, Zeithaml and Berryet all. (1985) [5] and Parasuraman (1988)'s [12] scales were taken together and perceived service quality was evaluated in 5 dimensions (Papatya, Papatya and Hamsioglu, 2012) [16]. Based on the results of the research it was observed that the lack of trust in state hospitals and problems in the polyclinics, the unpunctual timing of the appointment, and overcrowded number of the appointments in the service delivery are effective factors on preference of health care organizations. The Cronbach's alpha test was used to assess the reliability of the scales. The alpha value of the scale is greater than 0.70 and ranges from 0.71 to 0.83 as a result test value is considered as a sufficient.

\subsection{Aim of the Study}

The aim of the research is to investigate the effect of service quality of XXX State Hospital located in Turkey, on patient satisfaction, to examine the relationship 
between demographic variables and other variables, to determine the factors affecting service quality in the light of obtained data.

\subsection{Research Methodology}

The study was developed based on the questionnaire form of Varinli and Cakir (2004) [17] and Yağciand Duman (2006) [18] which was written on the effects of SSK Hospitals on the Quality of Service of the Transfer to the Ministry of Health (Tayyar and Bektaş 2008) [19]. The questionnaire form was firstly evaluated by experts and then by interviewing the "quality management representatives" of the hospitals. A pilot survey was made and some questions were abbreviated and changed. Patient satisfaction was taken from Dilseker (2011)'s [20] study and 3 statements about satisfaction on the questionnaire were changed and added to patient satisfaction (See Appendix A). These are:

1. I am satisfied with the service I have received in general.

2. The service I received from the hospital is fully fulfilling my expectations.

3. The service given I consider is satisfactory in general.

The questionnaire consists of two parts. There are 27 questions in the first section, the first 24 questions measure the quality of the service provided, and the last 3 questions measure the quality of satisfaction of the hospital in general. A seven-point Likert scale was used in the questions. 1 is a "Strongly disagree" and 7 if "Strongly agree". At the second part of the questionnaire, participants' demographic and socioeconomic information (age, gender, marital status, education, occupation, monthly income, place of residence, social security institution) are included. The reliability of the scales used (Cronbach $\alpha$ ) is 0.939 . This is also highly reliable, since the corresponding Cronbach Alpha value for satisfaction is 0.932 . The first section of the questionnaire was created from 4 dimensions. These include: doctor services, pre-service and physical services, examination services, nursery services.

Respondents were selected among the volunteer patients who wanted to participate in the study, 180 patients were asked to participate in this survey, 150 questionnaires were considered satisfactory, 30 of them were not evaluated due to lack of data. SPSS 21 (Statistical Package for Social Sciences) package program was used for analysis of the data.

\section{Key Research Findings}

\subsection{Demographic Findings}

A demographic analysis of 150 questionnaires ultimately directed us to the following results: 106 (70.7\%) were male and $44(29.3 \%)$ were female. The average age was 48.73 . The youngest age was 20 and the oldest patient was 81 years old. $140(93.3 \%)$ respondents were married, and $10(6.7 \%)$ of them were single. It was also found that 82 (54.7\%) of the participants were living at the center of the city where hospital located and $68(45.3 \%)$ of the participants were residing in districts of the city and elsewhere. 
Respondents were asked whether they would recommend this hospital to someone else.

$12(8 \%)$ evaluated as "medium", 36 (24\%) evaluated as "good" and $102(68 \%)$ evaluated as "very good". 150 (100\%) of respondents answered "yes" to recommending and re-choosing this hospital. Other questions were asked about patient rights and whether they were given the number to call when needed or when they were worried. 22 (14.7\%) were positive and 128 (85.3) people answered negatively whether they were informed about patient rights. 34 (22.7\%) people have been given phone numbers to contact, 116 (77.3) people have not been given the number. Data on demographic questions are shown in Table 1.

\subsection{Reliability Analysis}

Reliability analysis is used to see how reliable the questionnaire is. The result of the reliability analysis came out as Cronbach's alpha 0.760 . This suggests that the survey is highly reliable.

If $0.00 \leq \alpha<0.40$ the scale is not reliable.

Table 1. Summary of demographic findings.

\begin{tabular}{|c|c|c|}
\hline Gender & $\mathbf{N}$ & $\%$ \\
\hline Male & 106 & 70.7 \\
\hline Female & 44 & 29.3 \\
\hline Marital status & $\mathbf{N}$ & $\%$ \\
\hline Married & 140 & 93.3 \\
\hline Single & 10 & 6.7 \\
\hline Education level & $\mathbf{N}$ & $\%$ \\
\hline Can read and write & 29 & 19.3 \\
\hline Primary school & 38 & 25.3 \\
\hline Secondary school & 51 & 34 \\
\hline University & 30 & 20 \\
\hline Graduate & 2 & 1.3 \\
\hline Monthly salary, TL & $\mathbf{N}$ & $\%$ \\
\hline $300-500$ & 2 & 1.3 \\
\hline $500-750$ & 3 & 2 \\
\hline $750-1000$ & 5 & 3.3 \\
\hline $1000-1500$ & 59 & 39.3 \\
\hline Over 1500 & 81 & 54 \\
\hline Place of residence & $\mathbf{N}$ & $\%$ \\
\hline Center of the city hospital located & 82 & 54.7 \\
\hline Districts of the city and elsewhere & 68 & 45.3 \\
\hline
\end{tabular}


If $0.40 \leq \alpha<0.60$ the scale is low reliability.

If $0.60 \leq \alpha<0.80$ the scale is very reliable.

If $0.80 \leq a<1.00$ the scale is a highly reliable.

Results are as following: Reliability of the questionnaire about doctors' services is $0.678,0.713$ is for pre-service and physical services, 0.811 is for nurse services and 0.725 for examination services.

\subsection{Factor Analysis}

Factor analysis was used to measure relationships of the dimensions of the questionnaire. None of factor loadings was less than 0.30 . The result of the factor analysis is shown in Table 2.

Table 2. Factor loadings.

Rotated Component Matrix ${ }^{\mathrm{a}}$

\begin{tabular}{|c|c|c|c|c|}
\hline & \multicolumn{4}{|c|}{ Component } \\
\hline & 1 & 2 & 3 & 4 \\
\hline In general, cleanliness of hospital is sufficient. & & 0.622 & & \\
\hline The environment in the hospital is quite enough. & & 0.592 & & \\
\hline In-hospital signs are adequate and sufficient. & & 0.608 & & \\
\hline Physical facilities (buildings, decor, lighting) of the hospital are sufficient. & & 0.573 & & \\
\hline The staff in the registration department is kind. & 0.537 & 0.310 & & \\
\hline Registration is easy and fast. & 0.594 & & & \\
\hline Officers direct you with the division you need. & 0.673 & & & \\
\hline We make use of laboratory and medical services easily ( $\mathrm{x}$-ray, ECG) & 0.586 & & & \\
\hline Nurses listen to patients and understand their situation. & 0.723 & & & \\
\hline Nurses are respectful and kind to the patients. & 0.684 & & & \\
\hline Nurses show interest and closeness to the patients. & 0.615 & & & 0.385 \\
\hline The time doctors afford for the patient is enough. & & & & 0.497 \\
\hline Doctors are polite and kind to their patients. & & & 0.858 & \\
\hline Doctors show close interest and smile-face to their patients. & & & 0.903 & \\
\hline Doctors show sensitivity to patient privacy. & & & 0.821 & \\
\hline Doctors inform their patients about the treatments, tests and medications they apply. & & & & 0.628 \\
\hline It is easy to show the results of the examination to the doctor. & & & & 0.583 \\
\hline I am confident that the examination and treatment are done correctly. & & & & 0.528 \\
\hline Laboratory/Radiology officials are kind. & & & & 0.626 \\
\hline Laboratory/Radiology departments show sensitivity to patient privacy. & & 0.432 & & 0.464 \\
\hline Comfort and convenience are provided to patients during taking blood and other samples. & & 0.549 & & \\
\hline The sampler is attentive in his/her job, kind and helpful. & & 0.519 & & \\
\hline Hospital staff generally works in harmony with each other. & & 0.473 & & \\
\hline
\end{tabular}




\subsection{Independent Samples T Test}

This test helps us to compare the means of two sets of data. For example, we run a $t$ test to see if the average test scores of males and females are different; the test answers the question, "Could these differences have occurred by random chance?" There are some assumptions in the implementation of this test:

1. Assumption of normality: the dependent variable should be approximately normally distributed.

2. Assumption of Homogeneity of Variance: The variances of the dependent variable should be equal.

3. Assumption of Independence: we need two independent, categorical groups that represent our independent variable.

Hypotheses:

Ho: Gender categories and satisfaction dimensions are normally distributed.

$\mathrm{H1}$ : Gender dimensionality and satisfaction dimensions are not normally distributed.

According to "Skewness-Kurtosis", gender and satisfaction scales between the range of $(-1.5: 1.5)$ is in the normal distribution. Ho hypothesis has been supported. The gender and satisfaction dimensions are normally distributed.

Homogeneity of Variance:

Ho: The variances of the two samples are equals.

$\mathrm{H1}$ : The variances of two samples are different from one another.

Since sigma value is $0.165>0.05$, we can say that the variances are equal. We accept the Ho hypothesis. As a result of satisfying these conditions, we can apply the "Independent Groups t-test". We accept the hypothesis Ho because the analysis result is $p>0.05$. The effect on gender on satisfaction is significant. Findings related with the analysis are shown in Table 3.

\subsection{Contingency Table, Chi Square Test}

Contingency tables (also called crosstabs or two-way tables) are used in statistics to summarize the relationship between several categorical variables.

Ho: There is a positive relationship between the "gender category" and the "participants" evaluation.

$\mathrm{H1}$ : There is no positive relationship between "gender category" and "participants" evaluation.

Table 3. Independent samples T test.

\begin{tabular}{|c|c|c|c|c|c|c|c|}
\hline & \multicolumn{2}{|c|}{$\begin{array}{c}\text { Levene's test for equality of } \\
\text { variances }\end{array}$} & \multicolumn{5}{|c|}{$\mathrm{T}$ test for equality of means } \\
\hline & \multirow[t]{2}{*}{$\mathrm{F}$} & \multirow[t]{2}{*}{ Sig. } & \multirow[t]{2}{*}{ Sig.(2tailed) } & \multirow[t]{2}{*}{ Mean difference } & \multirow{2}{*}{$\begin{array}{l}\text { Std. Error } \\
\text { difference }\end{array}$} & \multicolumn{2}{|c|}{$\begin{array}{l}95 \% \text { confident } \\
\text { Interval of the difference }\end{array}$} \\
\hline & & & & & & lower & upper \\
\hline \multirow{2}{*}{ Satisfaction } & \multirow{2}{*}{1.945} & \multirow{2}{*}{0.165} & 0.296 & 0.07905 & 0.182 & 0.485 & \\
\hline & & & 0.230 & 0.07905 & 0.178 & 0.476 & \\
\hline
\end{tabular}


The $\mathrm{p}$ value of the analysis is greater than 0.05 and it drives us to accept the Ho and reject the H1: $\mathrm{P}(0.556)>0.05, \mathrm{x}^{2}=1.175$. The analysis results showed that the gender has an important impact on the participants' evaluation. Among males, 10 (9.4\%) answered "medium", 26 (24.5\%) answered "good", 70 (66\%) answered "very good". From females, 2 (4.5\%) answered as "medium" 10 (22.7\%) answered "good" and 32 (72.7\%) answered "very good". The result of the analysis is shown in Table 4.

\subsection{Correlation Analysis}

Correlation analysis is used to determine the presence and direction of the relationship between the two variables. Hypotheses established to make this analysis:

Ho: there is a linear relationship between service and satisfaction.

$\mathrm{H} 1$ : there is no linear relationship between service and satisfaction.

The result of the analysis showed that $0.215>0.05$. In this respect we accept the hypothesis Ho. There is a positive relationship between satisfaction and quality of service. An analysis of the correlation is given in Table 5.

Table 4. Contingency table.

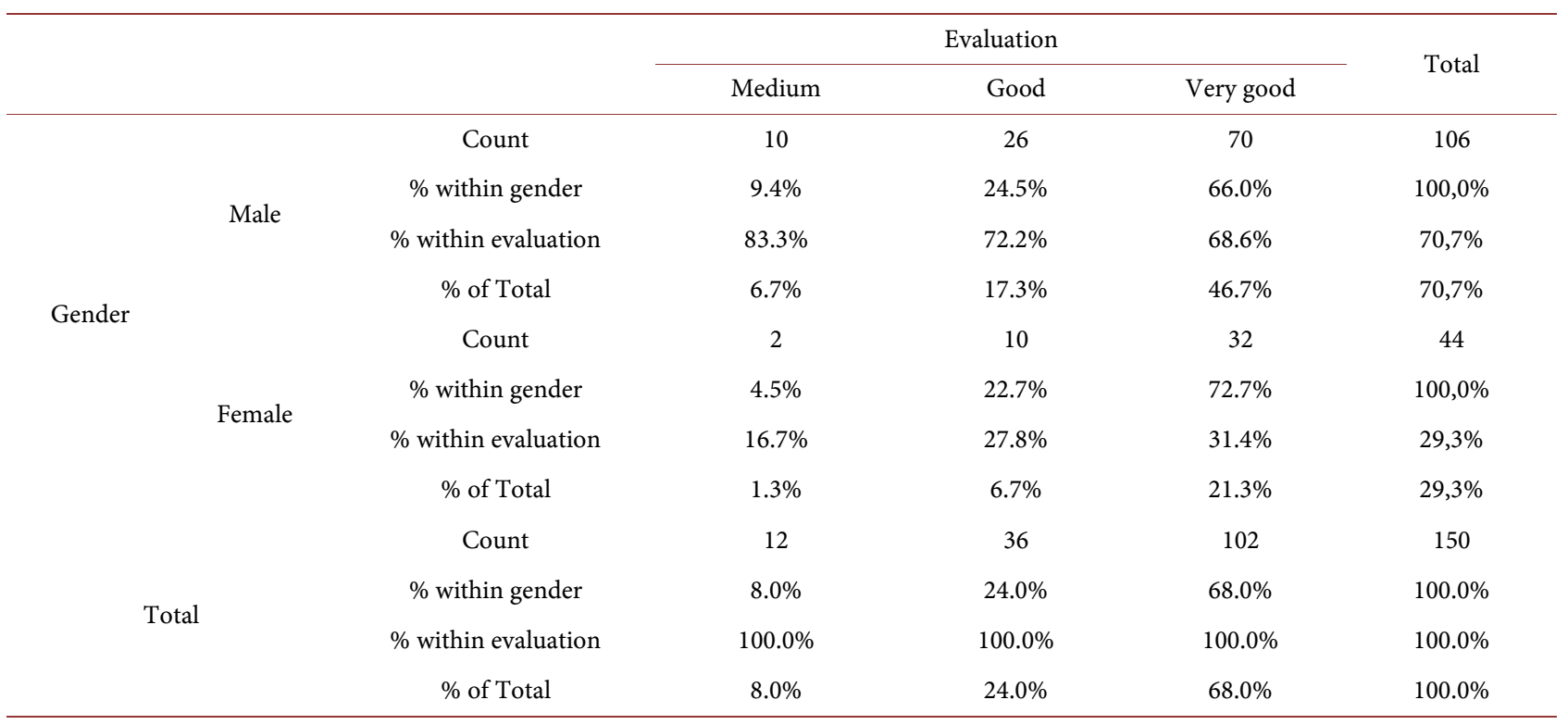

Table 5. Correlation analysis.

\begin{tabular}{|c|c|c|c|}
\hline & & satisfaction & service \\
\hline \multirow{3}{*}{ satisfaction } & Pearson Correlation & 1 & $0.215^{* *}$ \\
\hline & Sig. (1-tailed) & & 0.004 \\
\hline & $\mathrm{N}$ & 150 & 150 \\
\hline \multirow{3}{*}{ service } & Pearson Correlation & $0.215^{* *}$ & 1 \\
\hline & Sig. (1-tailed) & 0.004 & \\
\hline & $\mathrm{N}$ & 150 & 150 \\
\hline
\end{tabular}

**. Correlation is significant at the 0.01 level (1-tailed). 


\subsection{Regression Analysis}

As a result of the regression analysis, it is found that there is a significant relationship between service and satisfaction. Regression analysis was given in Table 6. Analyzes showed that doctors' services (0.187), pre-examination services $(0.148)$ and examination services $(0.060)$ have effect on the satisfaction respectively.

\subsection{Anova Test}

In order to apply the Anova test we established following hypotheses:

Ho: There is no positive relationship between participants' education and satisfaction.

H1: There is a positive relationship between participants' education and satisfaction.

We accept the hypothesis Ho since the analysis result is $0.806>0.05$. There is no positive relationship between participants' satisfaction and their education. The one-way ANOVA test is given in Table 7.

\section{Conclusions and Future Research Directions}

Regarding the delivery of healthcare services, there is increasing research on enabling people to benefit from public and private healthcare organizations systematically and unlimitedly, adopting information technologies to the health system, and prioritizing patient safety and satisfaction. From this perspective, regardless of the hospital types, increasing competition conditions and emerging patient-based approaches raise the importance of the quality aspect of delivering healthcare services. In this paper we conducted several examinations and it is found that there is a positive relationship between the "gender category" and the "participants" evaluation. Correlation analysis is used to determine the presence

Table 6. Regression analysis.

\begin{tabular}{cc}
\hline Dependent variable-Satisfaction & \\
\hline Independent variables & Beta value \\
\hline Doctors' services & 0.187 \\
Pre-examination services & 0.148 \\
Examination services & 0.06 \\
\hline
\end{tabular}

Table 7. One-way Anova test.

\begin{tabular}{cccccc}
\hline \multicolumn{5}{c}{ Satisfaction } \\
\hline & Sum of Squares & $\mathrm{df}$ & Mean Square & F & Sig. \\
\hline Between Groups & 0.318 & 4 & 0.080 & 0.404 & 0.806 \\
Within Groups & 28.588 & 145 & 0.197 & & \\
Total & 28.907 & 149 & & & \\
\hline
\end{tabular}


and direction of the relationship between service quality and patient satisfaction and was found that there is a positive relationship between satisfaction and quality of service. Besides that Anova test was conducted, results showed that there is no positive relationship between participants' satisfaction and their education.

In this paper, it is aimed to examine the relationship between patient satisfaction and medical services in state health organizations. Based on results of factor analysis of this study, it could be seen that determinants of satisfaction are not only related with the need for high financial costs and the development of complex medical technologies. It is worthwhile to note that, based on the results of the questionnaire survey and clarification of the patient's opinion, the following individual factors such as communicative skills of the staff, including goodwill, smile-face, politeness listening to patient complaints, showing sensitivity to patient privacy, detailed explanation of treatment, etc. play crucial role on patient satisfaction.

The main limit of the research was the fact that the research institution was the only hospital and the patients who completed the survey were selected from volunteer patients who wanted to participate in the study. However the authors sincerely believe that, the research results will shed light on future studies; will give hints to hospital managers, personnel working in the quality field in hospitals, and academicians, especially including policymakers. Results of this paper on the assessment of the quality of service, lead to the conclusion that patient-oriented staff is an essential indicator of the quality of medical services and the perceived value of the service. Depending on the results and conclusions obtained in these findings, it will be possible to contribute to other studies to develop new questionnaire to measure service quality and patient satisfaction at health organizations in the future. Besides that, as another future research issue, the effect of service quality on patient loyalty could be examined in depth.

\section{References}

[1] Cati, K. and Yilmaz, A. (2002) A Research on Patients' Perception of Hospital Service Quality. Marketing World, 16, 46-53.

[2] Stewart, R. (1999) Measuring Service Quality: Current Thinking and Future Requirements. Marketing Intelligence and Planning, 17, 21-34. https://doi.org/10.1108/02634509910253777

[3] Ibrahim, K. (2014) Perceived Service Quality in Healthcare Organizations and a Research in Ankara by Hospital Type. Journal of Ankara Studies, 2, 22-34.

[4] Zeithaml, V.A., Berry, L.L. and Parasuraman, A. (1988) Communication and Control Processes in the Delivery of Service Quality. Journal of Marketing, 4, 35-48. https://doi.org/10.2307/1251263

[5] Parasuraman, A., Zeithaml, V.A. and Berry, L.L. (1985) A Conceptual Model of Service Quality and Its Implications for Future Research. Journal of Marketing, 49, 41-50. https://doi.org/10.2307/1251430

[6] Parasuraman, Berry and Zeithaml (1990) An Empirical Examination of Relationships in an Extended Service Quality Model. Marketing Science Institute Research Program Series, 12, 90-122. 
[7] Adil, M., Mohammad Al Ghaswyneh, O.F. and Albkour, A.M. (2013) SERVQUAL and SERVPERF: A Review of Measures in Services Marketing Research. Global Journal of Management and Business Research Marketing, 13, 64-76.

[8] Christian, G. (1984) A Service Quality Model and Its Marketing Implications. European Journal of Marketing, 18, 36-44. https://doi.org/10.1108/EUM0000000004784

[9] Berry, L.L., Parasuraman, A. and Zeithaml, V.A. (1985) Quality Counts in Services, Too. Business Horizons, 5, 44-52. https://doi.org/10.1016/0007-6813(85)90008-4

[10] Lehtinen, U. and Lehtinen, J.R. (1982) Service Quality: A Study of Quality Dimensions. Working Paper. Service Management Institute, Helsinki.

[11] Ghobadian, R., Speller, S. and Jones, W. (1994) Service Quality Concepts and Models. International Journal of Quality Management, 11, 43-66.

[12] Parasuraman, A. (1988) Customer Service in Business-to-Business Markets: An Agenda for Research. Journal of Business and Industrial Marketing, 13, 309-321. https://doi.org/10.1108/08858629810226636

[13] McNealy, R.M. (1994) Making Customer Satisfaction Happens: A Strategy for Delighting Customers. Champan\& Hall, London.

[14] Yilmaz, F.O. (2010) The Factors Determining the Patient Satisfaction: An Application. Master Thesis, Afyon Kocatepe University.

[15] Sahin, T.K., Bakıcı, H., Bilban, S., Dincer, S., Yurtcu, M. and Gunel, E. (2005) Investigation of Hospitalized Patients' Relatives' Satisfaction in Pediatric Surgical Clinic of Meram Medical Faculty. Genel Tip Dergisi, 15, 137-142.

[16] Papatya, G., Papatya, N. and Hamsıoglu, A.B. (2012) Sağlk İşletmelerinde Algılanan Hizmet Kalitesi ve Hasta Memnuniyeti: Iki Özel Hastanede Karşılaștırmalı Bir Araştırma. [Perceived Service Quality and Patient Satisfaction in Healthcare Organizations: A Comperative Research in Two Private Hospitals.] Kirıkkale Univ. Social Sciences. Inst., 2, 87-108.

[17] Varinli, I. and Ç,akır, A. (2004) Hizmet kalitesi, değer, hasta tatmini ve davranışsal niyetlerar asındaki ilişki-Kayseri' de poliklinik hastalarına yönelik bir araștırma. [Relationships among the Service Quality, Patient Satisfaction, Perceived Value, and Behavioral Intentions-Research towards to the Polyclinic Patients in Kayseri.] Erciyes Universitesi Sosyal Bilimler Enstitüsu Dergisi, 2, 33-52.

[18] Yagc1, M.I. and Duman, T. (2006) An Analysis of the Relationship between Service Quality and Customer Satisfaction According to Type of Health Services Provider: An Application at Public, Private and University Hospitals. Dogus Universitesi Dergisi, 7, 218-238.

[19] Tayyar, N. and Bektas, C. (2008) The Effects of Transferring SSK Hospitals to Health Ministry on Service Quality. Finans Politik \& Ekonomik Yorumlar, 45, 73-87.

[20] Dilsheker, F. (2011) A Review of the Relationship between Service Quality, Student Satisfaction, Image, Loyalty and Recommendation. Master Thesis, Department of Business Administration, Social Sciences Institute, Usak University. 


\section{Appendix A: Survey Questionnaire}

\section{Doctors' services:}

Doctors show close interest and smile-face to their patients

Doctors are polite and kind to their patients.

Doctors inform their patients about the treatments, tests and medications they apply.

Doctors show sensitivity to patient privacy.

It is easy to show the results of the examination to the doctor.

The time doctors afford for the patient is enough.

\section{Pre-service and physical services:}

The staff in the registration department is kind.

Officers guide you to the division you need.

In-hospital signs (direction etc) are sufficient.

Registration is easy and fast.

\section{Examination services:}

Laboratory/Radiology departments show sensitivity to patient privacy.

Comfort and convenience are provided to patients during taking blood and other samples.

The sampler is attentive in his/her job, kind and helpful.

Laboratory/Radiology officials are kind.

I am confident that the examination and treatment are done correctly

\section{Nurse services:}

Nurses are respectful and kind to the patients.

Nurses show interest and closeness to the patients.

Nurses listen to patients and understand their situation.

\section{Satisfaction:}

I am generally satisfied with the service I received.

The services I have received from the hospital are fully fulfilled my expectations.

When I consider everything, the service given is satisfactory in general. 